Molecules'which are capable of fluorescence can often act as photosensitizers in photosensitized oxidations or in photographic emulsions, and they are sometimes also of some biological interest (for example, chlorophyll, carcinogenic hydrocarbons). As illustrated above, the striking feature of all these fuorescent molecules is that they are capable of reversible oxidation-reduction processes involving only simple electron transfer reactions.

It has been shown that these reactions are also responsible for their photosensitizing action ${ }^{1}$, and their biological significance is presumably also a result of this 'electronic reactivity'.

1 Weiss, J., Trans. Faraday Soc., 35, 48 (1939) ; Proc. Roy. Soc., A, 174, $351(1940)$

${ }^{8}$ Bowen, E. J., and Williams, A. H., Trans. Faraday Soc., 35, 765 (1939).

s Weil-Malherbe, H., and Weiss, J., NATure, 149, 471 (1942) ; 151, 449 (1943).

- Pringsheim, P., Trans. Faraday Soc., 35, 48 (1939).

${ }^{5}$ London, F., Compt, rend., 208, 2059 (1939).

- Mott, N. F., and Gurney. R. W., "Electronic Processes in Ionic Crystals;' (Oxford University Press, 1940).

\section{THOMAS JEFFERSON AS NATURAL PHILOSOPHER}

\section{BY DR. HARLOW SHAPLEY Harvard College Observatory}

$\mathrm{P}$ REVIOUS speakers [in the symposium arranged by the American Philosophical Society during April 22-24 to commemorate the two hundredth anniversary of the birth on April 13, 1743 of Thomas Jefferson] have easily encroached upon my subject, doubtless finding it difficult to consider the versatile Jefferson as a lawyer, a farmer, a diplomat, a traveller, without discussing also his thoughts and acts in the broad field of natural philosophy. Thus the famous contribution on the mould-board of the plough has been discussed, as well as the observations and speculations on climate, ethnology, and palæontology. My remarks can therefore be in the nature of miscellaneous supplementary notes.

Jefferson had a telescope. He was keenly and practically interested in surveying and navigating, and in the astronomical measurements required by such work, but he was in no sense an astronomer. His curiosity about the non-terrestrial was, however, healthy; and his admiration for the famous selftaught David Rittenhouse of Philadelphia brought him into frequent contact with practical and speculative astronomical questions. He used his telescope during the annular eclipse of the sun of September 17, 1811, and reported his observations both carefully and modestly. Towards the end of his life he used the telescope to watch, from his mountain home, the workmen building the University of Virginia.

Like all daring thinkers and workers in the pioneer days of so many of the sciences, Jefferson sometimes went to extremes. These misadventures were so few, compared with his successes, that one should not mention them at all except to prevent the impression that he was actually omniscient and infallible. Naturally he became cautious. When, for example, spectacular reports were made about shooting stars, he was sceptical. According to the Honourable S. A. Mitchill's account, Jefferson declined to accept the story of the meteoric fall in Connecticut in December,
1807. He did not like this Connecticut story ; and he did not like the way the Connecticut Yankees pronounced their Latin, either. There was, indeed, no love lost, for it is notorious how vigorously much of Connecticut disliked this Virginia advocate of religious tolerance. They reported showers of stones from the Connecticut clouds-he discounted the claims at once and said, according to Mitchill, that five words would be sufficient for a response. They were short words-" -It is all a lie !"

But later, when the evidence concerning the meteoric fall became clearer, Jefferson reconsidered the matter and recommended that competent authorities of the American Philosophical Society might look into it. $\mathrm{He}$ first pointed out, however, that the sending of the Connecticut stones to Congressmen was not necessarily the most profitable procedure, in view of the limitations of those particular gentlemen. The letter on the meteoric stones to Mr. Daniel Salmon is dated February 15, 1808, and is worth quoting as an illustration of Jefferson's scientific attitude.

"Sir, I have duly received your letter of the 8th instant, on the subject of the stone in your possession, supposed meteoric. Its descent from the atmospher presents so much difficulty as to require careful examination. But $I$ do not know that the most effectual examination could be made by the members of the National Legislature, to whom you have thought of exhibiting it. Some fragments of these stones have been already handed about among them. But those most highly qualified for acting in their stations are not necessarily supposed most familiar with subjects of natural history; and such of them as have that familiarity, are not in situations here to make the investigation. I should think that an inquiry by some one of our scientific societies, as the Philosophical Society of Philadelphia for example, would be most likely to be directed with such caution and knowledge of the subject, as would inspire a general confidence. We certainly are not to deny whatever we cannot account for. A thousand phen. omena present themselves daily which we cannot explain, but where facts are suggested, bearing no analogy with the laws of nature as yet known to us, their verity needs proofs proportioned to their difficulty. A cautious mind will weigh well the opposition of the phenomenon to everything hitherto observed, the strength of the testimony by which it is supported, and the errors and misconceptions to which even our senses are liable. It may be very difficult to explain how the stone you possess came into the position in which it was found. But is it easier to explain how it got into the clouds from whence it is supposed to have fallen? The actual fact however is the thing to be established, and this I hope will be done by those whose situations and qualifications enable them to do it."

Much earlier than the epoch of the meteor shower and the annular eclipse, Jefferson had developud a considerable interest in certain problems of cosmogony. During his long stay in France he had become acquainted with many of the leading men of science. Among them was the famous Buffon, the great naturalist and the encyclopædic writer on scientific subjects. Buffon got some of his biological specimens from Jefferson, and was generous enough to write, "I should have counseled you, sir, before publishing my Natural History, and then I should have been sure of the facts." It was a fine compliment, in the Parisian style. It is scarcely imaginable now that a 
man of science would seek the advice of a leading national politician in order to get his facts straight.

The "Epoques de la Nature", written by Buffon about 1780, received excited attention throughout Europe. It was but one part of the "Histoire Natiurel" with which he was long associated and which appeared during forty years in almost numberless volumes. One particular theory in "Epoques de la Nature" disturbed Jefferson. He wrote about it, in 1784, to the Rev. James Madison :

"It has occurred to me to reflect a little more on Buffon's central heat than I did at the moment of our conversation and to form an opinion different from what I then expressed. The term 'central heat' does not of itself give us a false idea of Buffon's hypothesis. If it means a heat lodged in the center of the Earth and diffusing its warmth from thence to the extremeties, then certainly it would be less in proportion to the distance to that center, and so forth. Of course less under the equator than the Poles, on high mountains than in deep valleys. But Buffon's theory is that this Earth was once in a state of hot fusion, and that it has been, and still continues to be cooling. What is the course of this process? A heated body being surrounded by a colder one, whether solid or fluid, the heat, which is itself a fluid, flows from the colder body equally from every point of the hotter. . .."

Jefferson, of course, subscribed to the current fluid theory of heat, universal at that time; but it is noteworthy that he also states one of the basic laws of thermodynamics. $\mathrm{He}$ goes on in the letter to Madison to reason that on the Buffon hypothesis the earth should be hotter at the poles than at the equator, contrary to observation, and contrary to the conclusion derived by Buffon, who says that the earth, being thinnest at the poles, will cool sooner there than under the equator where it is thicker. Jefferson concludes, "If my idea of the process of cooling be right, his is wrong and his whole theory in the Epochs of Nature is overset."

In general, the natural philosophy of .Jefferson was of the practical sort. Apparently he was some. what soured by the speculators on the origin and age of the earth. But he rather skilfully avoided the controversy of his time as to the origin of fossil shells on the mountain tops. He would not commit himself that they were remnants of the sea-line of the time, of Noah's Flood; or evidence of the rising ocean waters having covered the peaks; or one of those strange manifestations of the All-wise which permits shell-like formations' to grow through the ages in the same way that queer rock formations and crystals are formed without associated organisms.

His interest in geology was chiefly confined to a practical interest in mining and in the related field of palæontology. His enthusiasm for fossil bones led him to the inquiries and writings and collecting that have given him right to the title of founder of American palæontology. As has been told fully elsewhere, and many times, he brought along to the scientific men and museums of Philadelphia a collec. tion of remarkable bones when he journeyed to that city to become the Vice-President of the United States. Those fossils, one hundred and fifty years later, are on proud display. Later he built up at Monticello a much greater palæontological collection. It dominated the famous residence.

The steam engine was one of the practical scientific developments of his time that had a peculiar appeal to Jefferson. It inspired him to seek the possibility. not so much of transportation nor of man's manu. facturing, but rather the emancipation of the individual citizen from the drudgery of chores. He viewed the advances of science in terms of the practical problems of his plantation. If the tea kettle could only be developed into a practical steam boiler, the water could be pumped to the tops of the houses; the household machinery could be operated by water power, and hands released for the fields. Jefferson went from France to England especially to see Watt and his famous engine; but the canny inventor, or his advisers. saw to it that this shrewd and inventive Virginian did not get a close look at the details.

Thomas Jefferson was interested in the precious metals from two points of view-the coinage of the United States, and the mining industry. While VicePresident of the United. States he was attracted by the problems of the copper mines at Newark, New Jersey. Miss Adams has just recently published from the Boston Public Library a letter, heretofore unpub. lished, touching on this subject. Jefferson wrote to Elisha Boudinot in Newark concerning the resources of the Schuyler copper mines, which operated some three miles north of the town from 1719 until 1775 , and later. There is one sentence in that newly published letter which indicates an early contact of the Roosevelt family with the White House. Was it prophetic ? The sentence is, "As soon as you receive Mr. Roosevelt's answer I shall be further thankful for the communication of it." A matter of incorporation was involved, and one may assume that the awaited answer came in good time from Nicholas Roosevelt, who was the great-great-grand-uncle of some later tenants of the White House.

In 1790, when George Washington was President of the United States and Thomas Jefferson the Secretary of State, the latter was asked to make a report on weights and measures suitable for the new federation of States. The subject naturally interested one with such wide scientific and social interests as Jefferson, and one who had had close contacts with the reforms and innovations in France. He made recommendations that in a way resulted in the founding of the Bureau of Standards. More than twenty years later, Jefferson was writing to Dr. Robert Patterson concerning the project that the American Philosophical Society should look into the subject of fixing standards of measures, weights, and coins. He was a member of a committee charged with examining the problem. With a fine sense of the disadvantage of working with a committee from a distance, Jefferson modestly remarked, in the introduction to a long letter on the subject: "Isolated as is my position, I am sure I can offer nothing but what occurred to the committee engaged on it, with the advantage on their part of correction by an interchange of sentiments and observations among themselves. I will, however, hazard some general ideas, because you desire it, and if a single one be useful, the labor will not be lost."

It is of interest that a major part of this letter is devoted to the question of the appropriate diplomatic techniques necessary to get co-operation in Europe with an American innovation. All must be handled delicately, with full consideration of the prides and prejudices and sensitive vanities of the Governments of the foreign nations. He writes :

"With England, our explanations will be much more delicate;"-he is writing about the possibility of international agreement on a decimal system 
for weights and measures-"they are the older country, the mother country, more advanced in the arts and sciences, possessing more wealth and leisure for their improvement, and animated by a pride more than laudable ... The subject should therefore be opened to them with infinite tenderness and respect, and in some way which might give them due place ...." His approach reminds one of the techniques and tendernesses necessary at the present time in advocating international fellowship.

Jefferson makes an interesting commentary ("Writings", 13, 105) on the English gentleman as an amateur man of science. "We (in Virginia) are all occupied in industrious pursuits. They abound with persons living on the industry of their fathers, on the earnings of their fellow-citizens, given away by their rulers as pensions. Some of these, desirous of laudable distinction, devote their time and means to the pursuits of science, and become profitable members of society by industry of a higher order."

Returning to his consideration of units of weights and measures, Jefferson proposed, in one crystal clear sentence, unmatched in my experience for simplicity and completeness, the following :

"That our unit of measure then be a pendulum of such length as in the latitude of $45^{\circ}$, in the level of the ocean, and in a given temperature, shall perform its vibrations, in small and equal arcs, in one second of time."

His uncommon gift for clear writing could not be better illustrated. But his proposal was not accepted. His arguments against the unit of the one ten-millionth part of the distance from the pole to the equator were to the point. But it takes more than clarity and logic to simplify the deeply rooted system of weights and measures.

Jefferson's "Notes on Virginia" were among his most noteworthy writings. To me they demonstrate more clearly than anything else that if he had been free from his national political life he could have readily developed into one of the leading men of science of his time and country. His "Notes" touched all phases of the natural history of the region, and dealt with its people and its government. There were many editions, many translations. But he viewed his accomplishments with modesty. On September 25, 1785, he wrote to Francis Hopkinson: "I have sometimes thought of sending a copy of my Notes to the Philosophical Society as a tribute to them, but this would seem as if I considered them as worth something, which I'm conscious they are not. I will not ask you for your advice on this occasion, because it is one of those on which no man is authorized to ask a sincere opinion. I shall therefore refer it to further thought."

How many an editor has wished that his scientific contributors would refer their compositions to further thought !

The "Notes" were written in the war years, 1781 and 1782, and therefore we should make some allowance for Jefferson's rather stinging comparison of little America with Great Britain and great France, so far as the production of genius is concerned. His war-time comments on Britain : "The present war so long having cut off communication with Great Britain, we are not able to make a fair estimate of the state of science in that country. The spirit with which she wages war, is the only sample before our eyes, and that does not seem the legitimate offepring either of science or of civilization. The sun of her glory is fast descending to the horizon. Her philosophy has crossed the Channel, her freedom the Atlantic, and herself seems passing to that awful dissolution whose issue is not given human foresight to scan." For four hundred years worried men have predicted the impending dissolution of Britain. She has always been in a state of rapid decline !

One could continue at length with quotations that show the sensitiveness, the vast learning, the curiosity, and the originality of this astonishing Virginia farmer. He had, as they say, pretty nearly everything. In the field of natural philosophy he had caution and daringness, inquisitiveness and a willingness to change his mind in the light of new facts or as a result of further thought. What we would now call proper scientific methods and attitudes appeared to be instinctive with him.

His scientific creed is illustrated in his response to the Abbé Raynal's taunt, that America had produced no poet, no mathematician, or man of genius in any art or any science. In his "Notes on Virginia", Jefferson asked for time with regard to the poet; but pointed to Washington and Franklin (as well he might) as leaders in the soldier's craft, and the eraft of physies ; and concerning the Philadelphia astronomer he wrote, "We had supposed Mr. Rittenhouse second to no astronomer living; but in genius he must be the first, because he is self-taught. As an artist he has exhibited as great a proof of mechanical genius as the world has ever produced. [A famous orrery is referred to.] He has not indeed made a world; but he has by imitation approached nearer its Maker than any man who has lived from the Creation to this day." In a footnote he points out that the European nations traverse the globe with the aid of Hadley's quadrant, which was actually invented by the American Godfrey. But to return to the scientific creed. The Abbe Raynal later withdrew his taunt with regard to the North Americans; but still disparaged the South Americans. In a footnote Jefferson cyuestions the sufficiency of the Frenchman's knowledge, and the depth of his research on the subject concerning which he was writing. He indicated how the nationality and conditions of the' interpreter might well affect the interpretation, and concluded with the unforgettable statement:

"A patient pursuit of facts, and a cautious com. bination and comparison of them, is a drudgery to which man is subjected by his Maker if he wishes to obtain sure knowledge."

\section{THE WAY AND SPIRIT OF SCIENCE* \\ By Generalissimo CHIANG KAI-SHEK}

Chairman of the Military Affairs Commission of the Republic of China and Supreme Commander of the Chinese Armies

\section{The Scientific Approach}

DROCEED from the immediate to the distant, from the low to the high; attain the great through the small, the difficult through the simple. To

- Abridgment of an address by Generalissimo Chiang Kai-shek, given in 1942; translated by Huang Hsing-Tsung and Dr. Joseph Needham, F.R.S. Note that the word "Way" has a special signiflcance in Chinese philosophy. The address is posted in all Chinese Government laboratories and workshops. 